\title{
SERF1B wt Allele
}

National Cancer Institute

\section{Source}

National Cancer Institute. SERF1B wt Allele. NCI Thesaurus. Code C158540.

Human SERF1B wild-type allele is located in the vicinity of $5 q 13.2$ and is approximately 18 $\mathrm{kb}$ in length. This allele, which encodes small EDRK-rich factor 1 protein, may be involved in the development of the spinal cord and spinal column. 